\title{
The Impact of Energy ties on Russian Foreign Policy toward Turkey
}

\section{تأثير علاقات الطاقة على السياسة الخارجية الروسية تجاه تركيا}

\section{Dr.Ahmed Elbassoussy}

\section{Assistant Professor of Political Sciences,Egyptian Russian University.}

\section{Abstract:}

Energy resources have become fundamental determinants that control the course of relations between global powers. This is evident in Russian-Turkish relations, as Turkey is the main route for Russia's exports of hydrocarbons to Europe, especially after operating the Turkstream pipeline early 2020. On the other hand, Turkey relies mainly on Russia for its energy needs.

These close energy ties and mutual interdependence between Russia and Turkey contribute to formulating flexible Russian foreign policy towards Turkey, despite Turkish unacceptable external behaviors such as the Assassination of the Russian ambassador in Ankara, the downing of the Turkish warplane near the Turkish-Syrian border, as well as the evident divergences in attitudes and views between the two parties towards the Syrian crisis.

The research paper uses the theory of complex interdependence presented by neoliberal scholars, particularly Robert Keohane and Joseph Nye, as a tool to identify the impact of the energy interdependence on the Russian foreign policy toward Turkey.

The value of this research roots from the point that it incorporates the theoretical dimensions by casting light on the various perspectives of major 
international relations theoretical paradigms about the centrality of energy determinant in international politics. In addition to the empirical side, examining the impact of energy ties on Russian foreign policy toward Turkey.

\section{Keywords:}

Energy Resources- Foreign Policy- Russia- Turkey- Natural Gas- Black Sea.

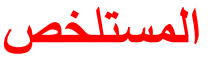

باتت مصادر الطاقة أحد أهم الدحدات الرئيسية التي تتحكم فى مسار العلاقات بين القوى الدولية، ويتجلي ذلك فى حالة العلاقات الروسية-التركية. فمن جانب تعتبر تركيا الممر الرئيسي لنقل صادرات الطاقة الروسية إلي أوروبا لا سيما بعد التشغيل الفعلي لخط غاز ترك ستريم أوائل عام • ·. . . بينما تعتمد تركيا بثكل أساسي على روسيا لتوفير احتاجاتها من الغاز الطبيعي. ساهم الاعتماد بين روسيا وتركيا فى في مجال الطاقة في صياغة سياسة خارجية روسية مرنة تجاه تركيا على الرغم من قيام تركيا بعدد من التصرفات غير المقبولة مثل اغتيال السفير الروسي في أنقرة، وإسقاط الطائرة الحربية التركية بالقرب من الحدود التركية السورية. وكذلك التباينات الواضحة في المواقف ترك تركي والآراء بين الطرفين تجاه الأزمتان السورية واللليبية. اعتمدت الدراسة فى تحليلها على نظرية الاعتماد المتبادل التي قُدمت من خلال مفكري الليبرالية الجديدة بخاصة روبرت كوهين وجوزيف ناي كأداة لتحديد دور الاعتماد المتبادل في مجال الطاقة على السياسة الخارجية الروسية إزاء تركيا. هذا، وترجع أهمية تلك الدراسة من كونها تجمع بين الثق النظري حيث أنها تتعرض لمركزية مفهوم الطاقة في النظريات الكبرى للعلاقات الدولية، علاوة على الجانب الأمبريقي باعتبار أنها تركز على تأثير روابط الطاقة على السياسة الخارجية الروسية إزاء تركيا. الكلمات المفتاحية: مصادر الطاقة- السياسة الخارجية- روسيا-تركيا- الغاز الطبيعي- البحر الأسود. 


\section{مجلة كلية السياسة والاقتصاد العدد الحادي عشر - يوليو I.Y.}

\section{Introduction:}

The energy determinant lies at the heart of Russia's global strategy, as it controls its pattern of interactions with almost all international and regional parties. Russia relies heavily on hydrocarbon export revenues to finance its public budgets, especially those destined for the European countries. Thus, the provision of safe and reliable export corridors comes on the Russian Federation's top priorities, which requires a significant degree of coordination with the neighboring powers, as well as generating an area of cooperation and joint interests to ensure the safety and continuity of supply operations.

Russian officials have found everything they need in Turkey, which has driven them to increase the intensity of their cooperative interactions after decades of severe historical conflicts, especially with the growing Turkish need to secure a reliable source of energy. These significant energy relations between the two parties contributed significantly to redirecting Russian foreign policy towards Turkey and reduced the severity of Russian reactions toward some Turkish actions that contradict its orientations, notably in the Middle East region.

\subsection{Main Question.}

This paper tries to explore the main research question, which is:

R Q. How does energy relations affect Russian foreign policy toward Turkey?

\subsection{Sub-Questions.}

In order to answer the previous question, the paper intends to find clarifications for the following sub-questions:-

Q 1: How the major theories in international relations dealt with the energy determinant?

Q 2: What are the conflictual aspects of Russian-Turkish energy relations? 
Q 3: What are the cooperational aspects of Russian-Turkish energy relations?

Q 4: What are the political implications of the energy ties on Russian foreign policy toward Turkey?

\subsection{Research hypotheses.}

To accomplish the objectives of this study, the research embark on the following hypotheses:-

$\mathrm{H} 0$. There was a significant influence of energy ties on Russian foreign policy toward Turkey.

$H$ 1. There was a limited influence of energy ties on Russian foreign policy toward Turkey.

\subsection{Literature review.}

Several scholars were interested in studying the impact of Russia's energy dimension on its foreign policy in general. Huotari (2011) believe that energy policy and security is a crucial component in Russian foreign policy. Russia uses its natural gas and oil exports as one of the most important tools for political gains, thereby expanding its influence and power. This appeared in the European case to the extent that it pushes the Europeans to describe Russia as an energy imperialist.

Mohapatra (2013) also claimed that Russian policymakers' strategic use of energy resources contributed to the growing status of Russia as an emerging power in the international arena, and the Russian foreign policy toward several major European energy clients validate this trend. He also mentioned that Russia is using its energy resources not only to bargain with external powers but also to employs similar to bye-off loyalty from its neighboring transit States, such as 
Ukraine and Georgia, as well as Caspian states where Moscow purchases energy at a cheaper price exploiting its position as a regional hegemon.

Lituhto (2010) emphasized that Russia's possession of unique energy capabilities qualify it to use energy as one of the effective tools of its foreign policy, most notably production and large reserves, as well as its high share of global hydrocarbon exports on which many global powers mainly depend on, especially, the European Union, which prompted Russia's consideration of "Energy Superpower".

On the contrary, Rutland (2008) concludes that Russia's concept as an energy Superpower exaggerates Russia's ability to use natural gas as a weapon to expand its influence over its neighbors and on the global level. However, energy can only be used as a hard power resource when merged with the other tools, such as military capacity and diplomatic bargaining.

Russian energy security faces several challenges that hinder the Russian ability to use energy as a useful foreign policy tool. Bogoviz et al. (2018) argued that the Russian energy security threats are divided into two categories:(1)Internal threats, such as economic, social, political, technological, and natural; and (2) External threats of international politics and economics that could reduce the energy security of Russia as an outcome of their accumulative actions or separately. The study also sheds light on various methods to face these challenges, like constructing transport and energy Infrastructure and promoting energy cooperation within the Eurasian Economic Union.

On the other hand, some studies discussed the different instruments and policies that Russia has resorted to face these serious challenges. Zhiznin (2010) asserted that Russia believes that international cooperation is the only useful tool 
to do so; therefore, he also highlighted the Russain cooperation initiatives, especially, in 2006 during the G-8 summit in Saint Petersburg, Russia introduced the adoption of documents on the principles of global energy security, which has been approved by the G-8 leaders. In April 2009, President Dmitry Medvedev suggested producing a document entitled "The Conceptual Approach to the New Legal Framework for Energy Cooperation: goals and principles”, an international legally binding document that would cover all aspects of global energy cooperation.

As for studies related to Russian policy towards Turkey, they are divided into two groups; the first includes a longitudinal review of the Russian foreign policy towards Turkey in different stages. Ersen (2011) reviewed Russian policy developments towards Turkey since the mid-1940s, which was marked by a great deal of hostility since each of them belonged to an opposing camp during the Cold War. During the 1960s, Russia sought to moderate its stance towards Turkey and open trade, industrial, and energy channels, but it was not achieved due to ideological differences. Although the end of the Cold War represented an opportunity to establish distinguished relations, however, relations deteriorated again in the 1990s due to Turkish attempts to penetrate the Soviet influence arena, mainly the Caucasus and Central Asia, as it left Turkey representing a geopolitical competitor to Russia in one of the most critical areas of its vital field.

Ustun (2016) asserted that the 2000s witnessed a new stage of Russian foreign policy toward turkey. After President Putin's arrival to power in Russia coincided with the Justice and Development Party's election in Turkey, Cooperation in achieving energy security has been one of the top priorities of both countries. The mutual interest between the two countries reflected increasing 
trade exchange volume reaching more than 24 billion dollars during the first nine months of 2014. It is worth noting that this stage has witnessed a focus on common aspects of their relationship, not conflict, which contributed to intensifying their diplomatic relations.

While the second group deals with Russia's policy towards Turkey on specific controversial events. Coskun (2011) chooses three main events to analyze its impacts on Russian policy toward turkey, which is: Russian air campaign against the Islamic State of Iraq and Levant (ISIL) and other anti-government forces on 30 September 2015, the Russian jet crisis on 24 November 2015, and the failed coup attempt in Turkey on 15 July 2016. Although there was a severe divergence between the two parties to the extent that the Russian side took a hard line towards Turkey. However, Russia accepted Turkish apologies and consequently adopted a flexible foreign policy towards Turkey. This is contrary to Russia's policy towards the failed coup attempt, as it has expressed support from the first moment of Turkey.

\section{Energy resources in international relations paradigms.}

The major international relations theories have concerned energy and resource security as a crucial determinant due to their central role in determining the hierarchy of countries in the international regime and their external behavior toward other global and regional actors. Energy resources considered a significant source of conflict or a tool to promote cooperation between states (ElBassoussy, 2019, P.69). ${ }^{(1)}$ It comes at the forefront of these theories: realism, liberalism, and institutionalism.

\subsection{Realist perspective about energy and resources.}


The intellectual roots of the realist paradigm in international relations goes back to the ideas of Nicolas Machiavelli in the sixteenth century and Thomas Hobbes in the seventeenth century (Bell, 2013) ${ }^{(2)}$ as well as the ideas of the Greek thinker Thucydides during the war between Sparta and Athens (Behravesh, 2010). (3) The realist paradigm divided into three leading schools: classical realism, neo-realism, or structure realism, (Stanford Encyclopedia of Philosophy, $2010)^{(4)}$ and neoclassical realism (Rose, 1998, 144). ${ }^{(5)}$

The German-American political scientist Hans Morgenthau is the modern founder of classical realism. This school depends upon several assumptions that govern its vision to the state and its relation with external parties, as well as the nature of the international system. Those assumptions as follows:-

- The state is the main actor.

- The state is a rational actor.

- The anarchic nature of the international system

- Power is the central concept in international relations.

- The conflictual nature of the international system (Donnelly, 2000, PP. 911). ${ }^{(6)}$

Classical realist scholars didn't tackle resources and energy security separately, but they refer to it while analyzing the importance of resources as one of the crucial elements that determine the state's strength besides military power. The most important contribution in this context is what Hans Morgenthau wrote in his book Politics Among Nations when he outlined elements of state power in geography, natural resources, industrial capabilities, military readiness, demographic composition, internal charters, and values, as well as the efficiency of the governmental and diplomatic system (Cesnakes, 2010, P. 33). ${ }^{(7)}$ 
According to Morgenthau, natural resources, including energy and raw materials, have become paramount in determining the strength of the state and its ability to cope with external threats and challenges, particularly after the growing role of technology in manufacturing processes during the industrial revolution. This has been demonstrated by the fact that it is no coincidence that the largest and most powerful states in the world system, like the United States and the former Soviet Union, had a sufficiency of raw materials and controlling the rest of the resources produced by other countries.

As Morgenthau has argued, oil gained extreme importance since the first world war, particularly with the excessive expansion of the arms industry. Thus, countries that have managed to control significant oil reserves have assumed a higher position and a strong influence on the international scene (Cesnakes, 2010, P.84). (8)

Despite relative divergence between Morganthau and John Herz's view on realism, resources also existed in Herz thought, considering that the exhaustion or lack of energy resources represented a fundamental threat to the security of nations and people, which must be taken into consideration by decision-makers (Herz, 1981, P. 46). ${ }^{(9)}$

Stephen Krasnar also focused on the significance of resources as one of the most central determinants that would increase the sovereign powers of states by gaining access and control over international resources such as water areas and oceans (Griffiths et. al, 2009, P.46). (10)

Global changes promoted neo-realists to propose another version of realism, in particular, Kenneth waltz, the founder of Neo-Realism or Structural Realism (Powell, 1994, P. 314). ${ }^{(11)}$ Waltz coined a comprehensive analysis framework to 
the System Structure, pointing to the importance of raw material Scarcities. Waltz argued that the increasing scarcity of raw materials would push the United States and other countries to rely mainly on external suppliers. He also pointed to the harmful effects of OPEC's control of oil prices and supplies that will consequently lead to more future scarcity for both raw and semi-processed (Waltz, 1979, P. 146).$^{(12)}$ However, Waltz believes that the state's power is derived from energy resources and many other sources. Therefore, he underestimated the importance of energy sources in influencing the state's behavior and its orientations toward other countries (Gurbanov, 2013). ${ }^{(13)}$

The neo-realist school encompasses two trends, the offensive realism, which is developed by the American political scholar, John Mearsheimer (Snyder, 2002, P. 150) ${ }^{(14)}$ assuming that the chaotic nature of international order pushes the superpowers to adopt a sharply offensive behavior towards other countries. According to Mearsheimer, the superpowers are always seeking to get more power against their opponents to achieve hegemony (Mearsheimer, 2001, P. 29). $\cdot(15)$

Mearsheimer implicitly refers to the role of energy resources in international relations while tackling the importance of wealth as a significant factor in determining the state's strength in the global world order. Due to Mearsheimer, economic wealth represents the cornerstone for the establishment of reliable military force which through could be used to dominate the international arena, and he gave an example by Russia, Germany, and France, whose international standing varied over the years as a result of fundamental imbalances in their economic potentials (Mearsheimer, 2001, PP. 66-67). ${ }^{(16)}$ 


\section{مجلة كلية السياسة والاقتصلاد العدد الحادي عشر - يوليو ا.Y.}

In other words, offensive realism does not concern wealth or resources unless it becomes a military force through which it can impose more control over the international arena against its enemies. Russian dependency over energy resources, mainly during Putin's era, could be seen as one good example of proving Mearsheimer's argument.

In contrast, the second trend is defensive realism, developed by American political scientist Stephen Walt in collaboration with Kenneth Waltz (Cesnakes, 2010 , P.41). ${ }^{(17)}$ It shows that even if the state has strong tendencies, the international system's chaotic structure will push towards the adoption of power balance status (Hamilton and Rathun, 2013, P. 445). ${ }^{(18)}$ Also, entering alliances to create balance even if accompanied by relative dependency will be less costly than conflict and wars (Walt, 1998, P. 15). ${ }^{(19)}$

Stephen Brooks has added a new factor of analysis. In his view, states are seeking to strengthen their share of economic capabilities to maximize their military power and use those resources to expand their influence on other international actors (Brooks, 1997, PP. 450-452). ${ }^{(20)}$ Moreover, both James Dougherty and Robert Pfaltzgraff emphasized that military power is not always capable of making the state or government sufficient power in the international system. The threat of energy security will weaken military security, and thus its energy security situation will determine the status of the state and its orientations in the international system.

Neoclassical Realism was more deeply concerned with energy and resource security than both classical and neo-realists. The neo-classical realists have linked energy resources with the foreign policy provided the state uses them as a tool to achieve its goals (Gurbanov, 2013). ${ }^{(21)}$ 
In this regard, Gideon Rose claimed that both relative resources and physical capabilities, including energy resources, are important determinants of a country's foreign policy but must be accompanied by political leaders and the ruling elite's understanding of how to use those capabilities, not just their size and quantity (Rose, 1998, P.146). ${ }^{(22)}$

William Wohlforth also gave great importance to resources as a variable in the possibility of describing a specific country as an international pole. Wohlforth believes that state must have a proper measure of the various components of power, especially population, land, resources, natural resources, economic capabilities, as well as military efficiency, to be described as an international pole (Wohlforth, 1998, P.10). ${ }^{(23)}$

Fareed Zakaria has linked wealth and the transformation of the state into a superpower. According to Zakaria, once the state's wealth is increased, it begins to expand outwardly to increase its influence on the international scene, which may be reflected in the increase of its military spending (Zakaria, 1998, P.12). ${ }^{(24)}$

Michael Klare is one of the most prominent neo-classical realist thinkers who have demonstrated the role of energy security in international relations. Klare believed that military power is not sufficient to express the state's power, but also energy resources became an influential factor that can generate conflicts. Several assumptions figured in Klare's writtings about this relation, which are as follows:-

-The end of the cold war and conflict between ideologies, particularly socialism on the one hand, and capitalism on the other, and the rise of new economic powers and poles, international relations have begun to focus on the acquisition and control of natural resources. Consequently, the world order has changed. 
Thus, conflicts between the major economic powers, especially the United States, China, Russia, Japan, India, and other countries, have become possible (Klare, 2001, P.50). ${ }^{(25)}$

- Oil has been transformed from being a commercial commodity purchased and sold on the international market into a strategic asset on the planet. Thus, its production, circulation, and distribution processes require more time, effort, and focus from senior officials, not only politicians but also military ones (Klare, 2008, P.7). ${ }^{(26)}$

- The Majority of energy supplies came from African and central Asian countries. These countries are characterized by fragility, vulnerability and suffer from internal conflicts, as well as the spread of religious extremism. Owning those countries' energy resources increase their influence on the international scene. However, their authoritarian ruling regimes are generally anti-west, which increases the possibility of rising conflict against western countries (Klare, 2009, P.47). (27) $^{(2)}$

Generally, although the distinguished concentration of various realist manifestations on hard power as the essence of managing the state's external relations. However, it also focused on some aspects of soft power, especially energy resources, as a tool of maximizing the power of the state, as well as its central role in increasing hard power outputs.

\subsection{Liberal perspective about energy and resources.}

Liberalism finds its roots in the ideas of John Locke, Jean-Jacques Rousseau, and John Stuart Mill. Both classical and neo liberalists share a set of principles and values, especially individual liberty, private property, and cooperation as a base for state relations, as well as equality and equal opportunities 
(Badie et.al, 2011). ${ }^{(28)}$ Based on the idea of accepting cooperation, liberal advocates argue that strategic resources, mainly energy sources, can be considered as a tool for promoting cooperation and not conflict, as mentioned before, by the realist perspective because they are tradable and can bring mutual benefits to all parties.

Therefore, liberals emphasize the importance of energy transmission pipelines as a tool that facilitates cooperation by promoting mutual gains through energy interdependence. This is a new contradiction with realists who asserted that these lines are only instruments used by governments to exploit more energy reserves to achieve objectives of a political nature, particularly the subjugation of other international parties, as well as dominating them.

In other words, liberals believe in absolute gains in energy, contrary to the realist Zero-Sum Game (Gücüyener, 2017). ${ }^{(29)}$ Liberal scholars asserted the possibility of achieving absolute gains for all parties through cooperation and institutional coordination to provide trust between exporters and importers. Exporters can increase their capacity as long as their oil production is rising, which is already achieved with increased proven reserves and enormous technological developments. Thus, liberals believe that the status of safe levels of energy security can be achieved through market mechanisms of supply and demand, particularly in the economies of major energy exporters, which are mainly based on the revenues of those exports to importing countries.

Interdependence has become increasingly important in international relations, especially among neo-liberalists such as Robert Khoane and Joseph Nye. Energy and resources have become increasingly important as one of the crucial determinants of international arrangements. They pointed out that the world is 
witnessing what is known as "The Era of Interdependence" (Keohane and Nye, $2012, P .3)^{(30)}$ that generated the significance of searching for common interests.

Therefore, neoliberal proponents have given importance to the role of international organizations, energy systems, and entities, particularly the International Energy Agency (IEA), as the instrument that can coordinate the divergent interests of countries through their organizational capacity (Keohane and Nye, 2012, P.288). ${ }^{(31)}$ However, this coordination process remains challenging with the absence of a global government and the necessity of integrating various parties like states, international bodies, multilateral institutions, and entities and non-state actors affected by the energy sector.

Accordingly, the energy sector still lacks the cooperation required, unlike other development areas that are more cooperative through economic institutions such as the International Monetary Fund (IMF), World Trade Organization (WTO), G20 , and other international organizations. The reasons for the lack of effective international cooperation in the energy field are the increasing degree of divergence among the various international actors. Moreover, the positive results of some parties' cooperation will lead to the benefit of other international actors that have not shown as acceptable for the cooperative parties (Keohane and Victor, 2013, P.99). ${ }^{(32)}$

Liberals interpretation of energy security faced several criticisms, the most prominent of which are the follows:-

- Ignoring the importance of the geographical location of resources.

- The incompatibility of the market force's role in achieving energy security, especially since several countries can use energy as a political weapon since 1973. 
- Many scholars are not convinced of the useful role of international and regional institutions and companies in achieving cooperation in the field of energy security, which is merely a tool for the capitalist countries that use them to control energy resources (Dannreuther, 2010, P.3). ${ }^{(33)}$

\subsection{Institutional perspective about energy and resources.}

The institutional theory includes a set of sub-theories (HistoricalSociological- Rational Choice Institutionalism) that aim to interpret international relations based on the concept of "institutions" by understanding and analyzing the meaning of institutions, rules, procedures, and structures, as well as the context in which they operate which affects their output and pattern of political behavior (Schmidt, 2014). ${ }^{(34)}$

Historical Institutionalists agreed with the proponents of the realist view that the scarcity of resources, including energy resources, is one of the leading causes of conflicts between different groups and countries. Therefore resources are the essence of politics. However, they offered a different interpretation of the role of political and economic institutional structures to achieve reconciliation (Hall and Taylor, 2014). ${ }^{(35)}$

In this regard, it worth noting that the institutions and organizations working in the framework of energy and their interrelated issues are divided into five main categories; International information organizations such as the International Energy Agency, the International Committee on Climate Change. International economic organizations, like the world trade organization (WTO), international law of the sea, and international arbitration. Sectorial institutions, in particular, the Kyoto Protocol. The internal institutions of the European Union, as well as private enterprises. 
Generally, the advocates of institutional interpretation of energy security believe that collective action within the framework of international or regional institutions or any coalitions can contribute effectively in achieving a safe level of security and in particular for the security of supply, through the following:-

- Promote knowledge and information cooperation on energy issues and other interrelated topics, for instance, the environment.

- Establishment of new institutions with compulsory legal status through signing collective multilateral agreements.

-Conducting new specific agreements directly related to regulating global energy markets.

- Establishment of new regional economic institutions focusing mainly on internal energy practices.

-Creating cross-border institutions from entrepreneurs and private trade organizations (Belyi, 2010). ${ }^{(36)}$

\section{Energy and the Russian Economy.}

The Russian economy depends heavily on oil and gas revenues, where the contribution of Russian exports of natural gas and oil in 2018 constituted about $40 \%$ of the total Russian budget. Higher oil product prices would achieve, according to the statement of the Russian Ministry of Finance budget surplus for the first time since 2011 of $0.45 \%$ of GDP instead of a $1.3 \%$ deficit of GDP for the previous period.

In 2018 Russian revenues from oil and gas sales reached US\$44.4 billion, equivalent to 2.74 Trillion Russian rubles, up from US $\$ 8.5$ billion, which is around 527.6 billion rubles, according to a budget amendment by the Finance Ministry. 
It worth to be mentioned that Russian oil and gas exports in 2018 constituted approximately $52.9 \%$ of total exports (Workman, 2020). ${ }^{(37)}$

Figure (1)

Russian Oil and Gas Exports VS Other products in 2018 (\%)

RUSSIAN OIL AND GAS EXPORTS VS OTHER PRODUCTS

IN $2018(\%)$

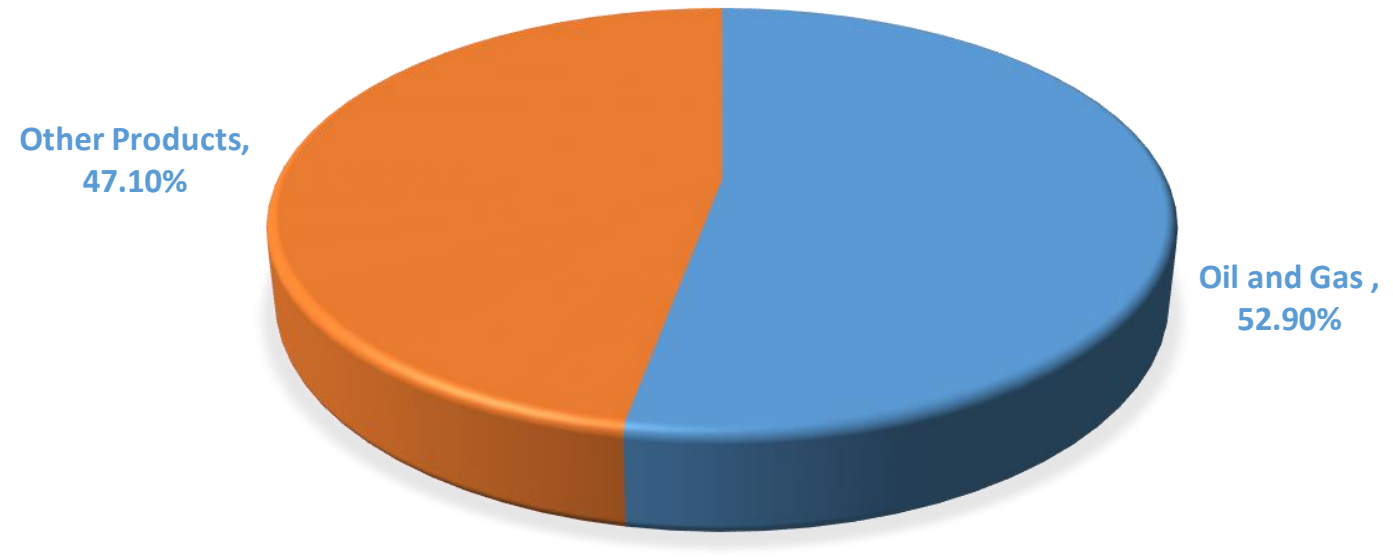

Source: Own Elaboration based on World Exports data 2020

http://www.worldstopexports.com/russias-top-10-exports/

\subsection{Russia in global energy balance.}

The Russian Federation is one of the most important actors in the equation of global energy in terms of production, proven reserves, and its significance in international energy trade as one of the world's largest exporters of various kinds of energy resources. In terms of production, Russia remained the third-largest oil producer during 2018, with 11.4 million barrels per day, which increased by $1.6 \%$ over the previous year 2017. And that after both the United States with 15.3 million barrels per day and Saudi Arabia, Which has a daily production of 12.2 million barrels (British Petroleum, 2019, P.16) . (38) 
Figure (2)

Global Oil Production by country in 2018 (\%)

Global Oil Production by country (\%) in 2018

$16 \%$

$13 \%$

- USA

- Saudi Arabia

$59 \%$

Russia

$12 \%$

Rest of World

Source: Own Elaboration based on data of British petroleum statistical Review 2019

Russia also ranked second in the world in the production of natural gas in 2018 with a total of 669 billion cubic meters, an increase of $5.3 \%$ from the previous year, after the United States, which ranked first with a total production of 831.8 billion cubic meters (British Petroleum, 2019, P.32). ${ }^{(39)}$

Figure (3) Natural Gas Prodution by country in 2018 (\%)

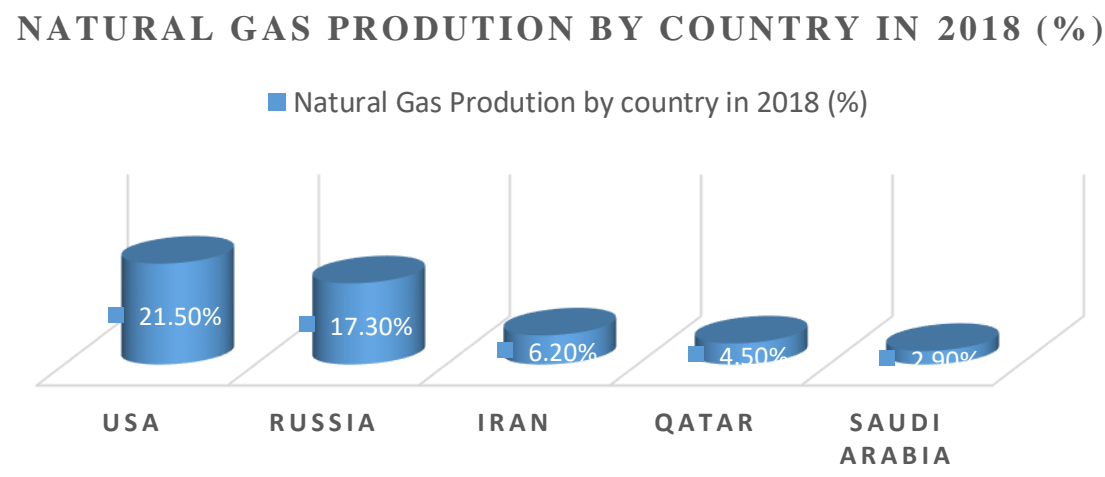

Source: Own Elaboration based on data of British petroleum statistical Review 2019 
In terms of proven reserves, Russia tops the world's natural gas with 1375 trillion cubic feet, equivalent to $19.8 \%$ of the world's proven reserves, about $3.6 \%$ difference of its nearest competitor Iran, whose territory contains $16.2 \%$ of the total proven world natural gas reserves (British Petroleum, 2019, P.30). ${ }^{(40)}$ Russia ranks sixth in terms of proven oil reserves in 2018 , with a total of 106.2 thousand million barrels, equivalent to $6.1 \%$ of the world's total proven oil reserves. While Venezuela on the top with around 303.3 thousand million barrels, followed by Saudi Arabia reaching 297.7 thousand million barrels, followed by Canada, which constituted 167.8 thousand million barrels, then Iran by 155.6 thousand million barrel, and Iraq in the fifth rank with reserves of 147.6 thousand million barrels (British Petroleum, 2019, P.14). ${ }^{(41)}$

Figure (4) Oil Proved reserves by country in 2018 (\%)

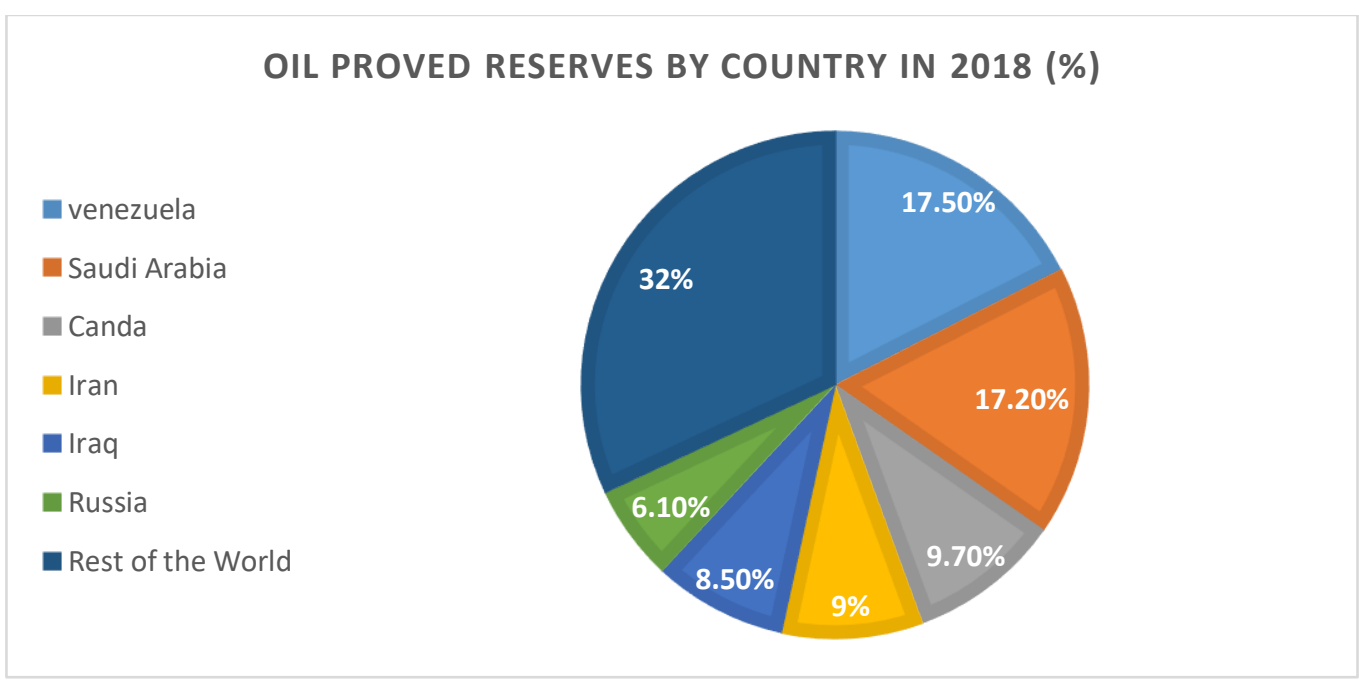

Source: Own Elaboration based on data of British petroleum statistical Review 2019

Concerning exports, Russia ranks among the world's top energy exporters. In terms of natural gas world exports, Russia ranked first by the end of 2018 , with total exports reached 247.9 billion cubic meters, equivalent to $26.3 \%$ of the entire 
world exports, including 223 billion cubic meters of pipeline gas, and 24.9 million cubic meters of LNG (British Petroleum, 2019, $38^{(42)}$.Russia is also the secondlargest crude oil exporter after Saudi Arabia, accounting for 275.9 million tons of crude oil, and ranked the second after the United States of America with regards to oil products exports by 173.1 million tons in 2018(British Petroleum, 2019, P.29). ${ }^{(43)}$

\subsection{Russian energy strategy.}

Three primary documents that define Russian energy strategy. The first one is known as the "Energy Strategy of the Russian Federation up to 2020". The main aim of this strategy, which is implemented on 28 August 2003 by Decree $N^{\circ} 1234-$ $r$ of The Russian Government, is to maximize the use of proven and potential energy resources to maintain the purposes of economic growth and improving the quality of life (Campos, 2018, P.51). ${ }^{(44)}$

The second document is acknowledged by the "Energy Strategy of Russia for the period up to 2030 " approved by Decree $N^{\circ} 1715-r$ of the Russian Federation government dated 13 November 2009. The primary purpose of this document appeared as it identified new guidelines for the development of the energy sector in the transition of the Russian economy to the innovative path of development" (Ministry of Energy of the Russian Federation, 2010, P.10). ${ }^{(45)}$

The accelerating pace of economic and social developments have pushed Russian officials to modify rapid adjustments to the previous two strategies, which may be considered the driving force that contributed to the issuance of the Russian energy strategy until 2035 (Campos, 2018, P.52). ${ }^{(46)}$ The ES 35 included several goals, which are as follows:-

Sustaining Russia`s position in global energy markets. 
Diversifying energy exports towards Asian markets.

$>$ Ensuring energy availability and affordability for the domestic market.

$>$ Reducing energy intensity and emissions.

$>$ Developing renewable energy systems (Mitrova and Yermakova, 2019, P.13). ${ }^{(47)}$

\section{Cooperational axis in Russain Turkish energy relations.}

One of the most crucial dimensions of cooperation between Russia and Turkey is the significant Turkish dependence on Russian energy sources, especially natural gas. By the end of 2018, Turkish imports of Russian gas amounted to 22.8 billion cubic meters, and in second place came Azerbaijan with 7.6 billion cubic meters, then Iran with 7.2 billion cubic meters. It worth to be mentioned that Turkish natural gas imports from Russia constitute around $10 \%$ of total Russian global exports (British Petroleum, 2019, P.40)..$^{(48)}$

Figure (5) Turkey Imports of Natural Gas by country as of 2018 (\%)

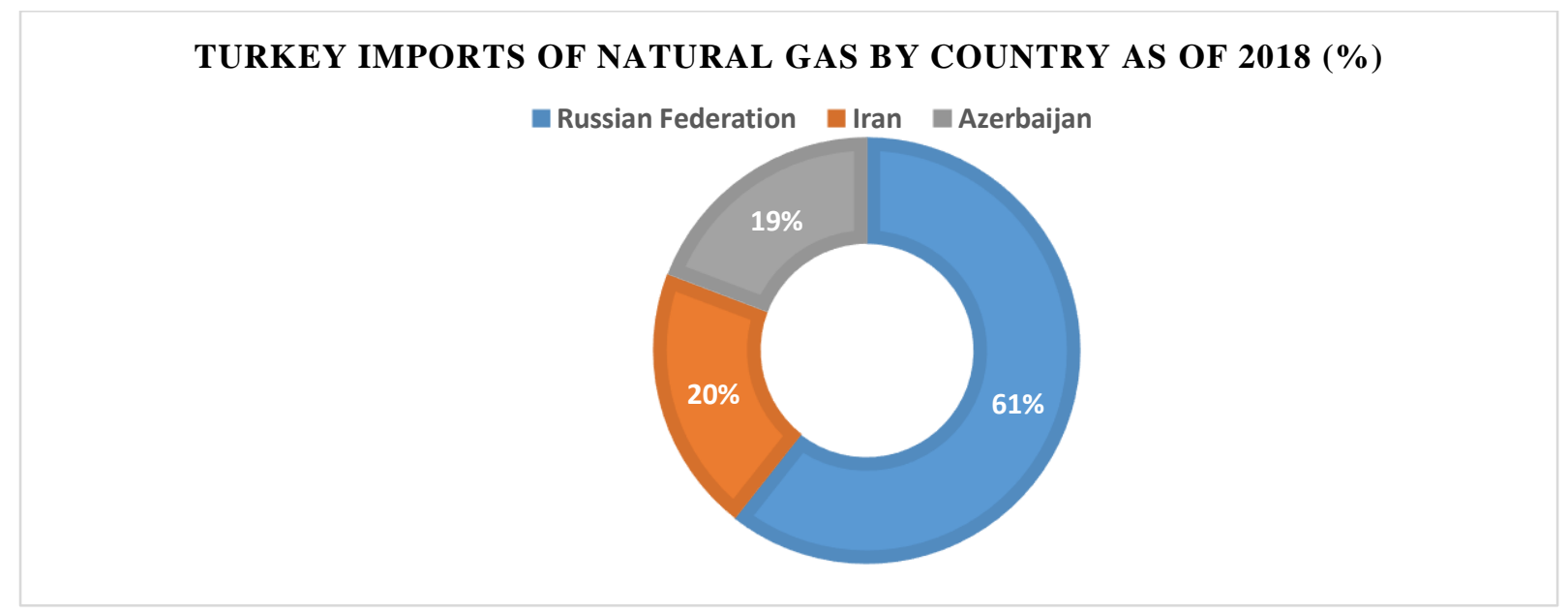

Source: Own Elaboration based on British Petroleum statistical Review 2019

Russian exports of natural gas to Turkey mainly flow from the Blue Stream pipeline. This major project is carrying natural gas from Russia to Turkey across 
land and the Black Sea. The pipeline is owned and operated by Blue Stream Pipeline BV, which is a Netherlands joint venture between Russian Gazprom and Italian company ENI (Hydrocarbons Technology, 2019). ${ }^{(49)}$

The start of pumping Russian natural gas to Europe through Turkey via the Turkish stream Pipeline beginning from January 1, 2020, is considered a quantum leap in Russian-Turkish cooperation in the field of natural gas (Eurasia review, 2020). ${ }^{(50)}$

It worth to be mentioned that the initial point of natural gas feeding is the Russkaya compressor station, which represents part of Russia's Unified Gas Supply System and is found close to Anapa. The pipeline is composed of two strings with more than 930 kilometers to the Turkish coast, where natural gas enters the receiving terminal, with a capacity of 31.5 billion cubic meters of gas per year, knowing that the first string is aimed to afford gas needs to the Turkish consumers, while the other one is providing gas supplies to southern and southeastern Europe (Gazprom, 2020). ${ }^{(51)}$

The importance of the Turkstream pipeline is since it attains plenty of strategic interests for both parties that exceed economic and financial returns to include security, political, and geo-strategic dimensions.

On the Russain level, this project will benefit the Russians through several dimensions, which are as follows:-

A. Strengthening its relations with the Turkish side, will relatively exclude Turkey from its European allies, as well as contributes to strengthening its influence internationally (Eurasia review, 2020). ${ }^{(52)}$

B. By Passing Ukraine in exporting natural gas to Europe by creating an alternative gas route. In doing so, it seeks to accomplish two things, 
ensuring the continuity of supply operations that are often under threat, especially after the arrival of the hostile political regime to Russia in Kyiv. In addition to depriving Ukraine of critical financial resources amounting to $\$ 3$ billion that was paid by Russia as transit fees annually to export its natural gas to Europe. The plan to bypass Russian gas exports via Ukraine is not a result of the moment but is old, in which Russia took previous steps, especially in 2011 after the completion of the Nord Stream 1 pipeline to export Russian gas to Germany directly via the Baltic Sea without the need for Ukraine, as well as its endeavor to establish the Nord stream 2 to bypass Ukraine, as well as the new Turkish Stream pipeline (Prince, 2020). ${ }^{(53)}$

C. Bnefiting from using the Turkish Economic Exclusive zone, without any significant concessions (Zender, 2019). ${ }^{(54)}$

D. Increasing Russian energy domination over Europe. Despite European efforts to decrease its dependency on Russia and diversify energy resources, many European countries are still heavily dependent on Russian gas. With this new pipeline, that dependency is not getting any less. On the contrary, it will increase (Bauomy, 2020) ${ }^{(55)}$ as the new constructions: Turkstream and Nord stream 2 will pump around 87 billion cubic meters of Russian gas, which will intensify European energy dependency on Russia (Coyle, 2019). ${ }^{(56)}$

E. The pipeline will partially limit the impact of Western sanctions. Following the Ukraine crisis, the Russian economy went into crisis and has not recovered yet. Thus, the revenues from exporting gas through the new pipeline will boost the Russian exports (Xiaoqiong, 2020). ${ }^{(57)}$ 
On the other hand, Turkstream Pipeline will provide Turkey with many advantages and strengthen its global position as well as its regional influence. This is manifested in the following:-

A. Ensuring Turkish energy security. However, Turkey is considered a poor country in terms of energy resources, as its imports constitute more than $75 \%$ of its energy needs. This new pipeline project that passes through its territory will ensure obtaining its natural gas needs as corridors. Thus this project will contribute to providing a safe level of energy security, especially from Russian gas (Saygin et al., 2018). (58)

B. Consolidating Turkish position as an energy hub. Turkey has sought over many years to utilize its geographical location to create distinct geostrategic importance. In this context, it mainly relied on conducting agreements with neighboring countries, which are rich in hydrocarbon resources, especially Central Asian states, Iran, and Russia, to establish corridors to transport natural gas to Europe (Tekin and Walterova, 2007). (59) And that appeared in the establishment of enormous energy transmission pipelines network passing through its territory and connected pipelines in those countries, among the most important of which is; TransAnatolian Natural Gas Pipeline (TANAP) with more than 1841 kilometers long that transfer Azerbaijan natural gas to Europe (Reuters, 2019). ${ }^{(60)}$

C. Acquisition of additional financial resources. The route of Turkstream through its territory will give it the right to collect transit fees, which help in balancing its energy trade deficit.

F. Increasing Turkish influence vis-a-vis the United States and the European Union. Inconsistencies between the US and Turkey over Kurds, Syria, and other issues have intensified in previous years. Consequently, 


\section{مجلة كلية السياسة والاقتصاد العدد الحادي عشر - - يوليو اب.r.}

stronger strategic cooperation with Russia will allow Turkey to align itself with Russia against the United States (Xiaoqiong, 2020). ${ }^{(61)}$

\section{Conflictual axis in Russian Turkish energy relations.}

These Russian-Turkish energy relations were not free of some contradictions and differences; foremost among them was the dispute over the establishment of the Baku Tbilisi Ceyhan (BTC) oil pipeline (Tiftikçigil and Yesevi, 2014, P.63). ${ }^{(62)}$ It is a long crude oil pipeline with a 1768 Kilometer that carries Caspian sea oil, particularly from the "Chirag-Gunashli" oil field in Azerbaijan to Baku, the capital of Azerbaijan, via the Georgian capital, Tbilisi, to Ceyhan port in Turkey (Persee, 2016, P.1). ${ }^{(63)}$

Despite the continuous Russian rejection of the project, Turkey has maintained its position to complete it due to the various advantages that Turkey obtained from it. The most prominent of them are as follows: -

A. Enhancing the geopolitical importance of Turkey. This pipeline contributed significantly to increasing Turkey's geopolitical stance, especially among the Europeans, as it is one of the crucial routes of Caspian oil transport to Europe. Hence, this pipeline helped in strengthening Turkey's position vis-a-vis Europe. Therefore, it represents a pressure card that Turkey can use in any case if the relations between them deteriorated.

B. Adding more financial and economic revenues. As Turkey becomes a transit country, so it will receive around $\$ 300$ million as transit and operating fees.

C. Decreasing the unemployment rate. The construction of this pipeline has been very positive for employment rates in Turkey. According to the Turkish company BOTAS, figures more than 5,000 people have worked in the pipeline's construction process. In addition to creating 400 permanent jobs 
once the line starts operating, as well as creating a significant number of supporting industries jobs (Baran, 2005, P.109). ${ }^{(64)}$

At this stage, the Russian Turkish relations went into severe tension. Russia pursued various ways to hinder the project's completion. It would provide an alternative for Russian resources, which is very dangerous for the Russian economy, as it depends mainly on oil and gas exports, mostly to Europe. However, Russian attempts were unsuccessful and could not prevent the construction of the pipeline (Baran, 2005, P.115). ${ }^{(65)}$

The Russian-Turkish disparities over energy issues did not cease at this stage, as it spread to an indirect dispute over the proposal of establishing Nabucco gas pipeline in 2002, which is responsible for transferring central Asian and Caspian sea natural gas, in particular, Azerbaijan, to Bulgaria and Austria via Turkish territory (Hydrocarbons Technology, 2002). ${ }^{(66)}$

In return, Russia proposed a new gas pipeline project as an alternative to Nabucco, Known as "Southern Stream"(Gotev, 2012). ${ }^{(67)}$ This pipeline project intended to transfer Russia's natural gas through the black sea to Bulgaria, Serbia, Hungary, Slovenia, and Austria (Offshore Technology, 2008). ${ }^{(68)}$

While, on 1 December 2014, after a formal meeting between the Russian president and his Turkish counterpart, Gazprom announced that the South Stream project had been canceled $(B B C, 2014)^{(69)}$ due to the failure of the Bulgarian government in providing assurances that the pipeline could be installed, as well as the European commission failure in assurances that gas would be allowed to through them (Stren et.al, 2015, P.5). ${ }^{(70)}$

\section{The Political implications of energy relations on Russian foreign policy} toward Turkey. 


\section{مجلة كلية السياسة والاقتصاد العدد الحادي عشر - يوليو I.Y.}

The state of cooperation and even interdependence between the Russian and Turkish parties in the energy field has overshadowed all political interactions between the two partners to the extent that it has influenced Russian foreign policy towards Turkey. Despite the eruption of many events that almost disturbed those relations, the energy determinant had the most considerable influence in calming the atmosphere between the two parties, which is manifest in the following:-

(1) Syrian conflict and Russian foreign policy toward Turkey: The Syrian crisis, showed a vast difference in visions and positions between Russia and Turkey. Russia has provided unprecedented political, military, and strategic support for Bashar al-Assad, seeking to keep his power, whatever the implications for this, not only in Syria but in the region as a whole (Jones, 2017). ${ }^{(71)}$ On the other hand, Turkey has expressed intense hostility toward al-Assad that has reached bloody military confrontations between the two sides on several occasions (kasapoğlu et.al, 2015, P. 3). (72)

Despite this significant divergence and conflicting interests between Russia and Turkey, especially after the Turkish president announced the necessity of overthrow Bashar al-Assad (Barnard, 2017), ${ }^{(73)}$ against the backdrop of the recent escalation in Idlib between Turkey and the Al-Assad regime backed by Moscow. Consequently, Turkish president Recep Tayyip Erdogan has threatened al-Assad with launching direct military action if any more Turkish troops are harmed in escalating fighting over Syria's last rebel stronghold (McKernan, 2020). ${ }^{(74)}$

But, the relations between Russia and Turkey didn't deteriorate, and that appeared in the statement of the Russian foreign minister, Sergey Lavrov, at the 
annual Munich Security Conference in Germany on 15 February, 2020, asserting that "We have excellent relations with Turkey, that does not mean we have to agree on everything. Full agreement on all issues cannot be possible between any two countries" (Gebert, 2020). ${ }^{(75)}$

These statements were formally reflected on 5 March 2020, when the two sides signed the agreement to end the crisis in Idlib, where the agreement included three main points, namely:

First: Ceasefire, starting at midnight on the signing date.

Second: Establishing a safe security corridor on both sides of the M4 international road, $6 \mathrm{~km}$ north and south of it.

Second: conducting joint Russian-Turkish patrols starting from the fifteenth of this march between Tarnabeh (West Saraqib) and Ain al-Hoor in the southern countryside of Idlib.

However, the agreement was intentionally neglected due to the dispute, essential points, foremost among the future of the areas controlled by the regime, the Turkish observation points, the Headquarters for the Liberation of Al-Sham, and the situation Saraqib. It almost wholly abandoned any talk about the mechanisms of implementation, monitoring, as well as setting any time limit, to the extent that the details of the safe passage will be determined by the defense ministers of the two countries within seven days. Based on the preceding, the agreement cannot be considered an integrated one but rather a temporary truce to defuse the crisis between the two countries (Roth, 2020). ${ }^{(76)}$ Thus, there is apparent Russian tolerance toward Turkey, despite the presence of severing differences, and that is considered relatively strange to the strict Russian approach in most cases against any country that could threaten its interests. This 
is due to the unique relationship between them in many other areas, especially in energy and advanced weapons deals.

(2) Russian policy toward Turkish energy activities in the eastern Mediterranean: Russia is dealing carefully with this file due to its extreme importance for Turkey, as well as its extending effects to many of the regional powers with which it has good relations. However, it appears that Russia is providing indirect support to Turkey that could reach the level of cooperation in the next stage as long as there is no conflict of interests. Several indicators prove this Russian indirect support, which is:

(a) Russia's reluctance to participate in any exploration operations with a direct Turkish rival, especially Cyprus: Although Russia sought to intensify its presence in the Eastern Mediterranean region, which prompted it by concluding energy investment agreements with Egypt, Israel, Syria, and Lebanon, it did not seek to cooperate with its Cypriot opponent, as the turkey will consider any Russian-Cypriot cooperation as a hostile step against it (Starodubtsev, 2019). ${ }^{(77)}$

(b)Russia has not criticized the Turkey-Libya Maritime Border agreement: Contrary to the European position rejecting the agreement expressed in the EU's leaders statement on 12 December 2019, which confirmed that the agreement "infringes upon the sovereign rights of third states, does not comply with the Law of the Sea and cannot produce any legal consequences for third states" (New Europe, 2019). ${ }^{(78)}$ And also, the American stance that describes the maritime zone agreement as unhelpful and provocative (Ahval, 2020). ${ }^{(79)}$ However, Russia has not commented on the agreement despite its explicit criticism of the security agreement that was signed on the same day between 
the two parties. This means that there is implicit Russian acceptance or at least no objection to the Turkish activities in the eastern Mediterranean.

(c) Russian enthusiasm to cooperate with Turkey in its eastern Mediterranean energy activities: The accelerated pace of Turkish exploration activities in the region promoted the Russian Minister of energy, Alexander Novak, in July 2019 on the sideline of the 16th meeting of the Joint economic committee between Russia and Turkey to express his country will cooperate with Turkey in the energy field as with other countries in the region (Ahval, 2019). ${ }^{(80)}$

(3) Eu and NATO dimension in Russian policy toward Turkey: Russian relations with the European Union and NATO are witnessing a constant tension, as both sides seek to weaken each other and expand their political influence globally. Russia seems to have taken advantage of the relatively tense relations between Turkey and the European Union due to the divergence in several issues, especially the refugee dilemma, and Turkey's accession to the European Union to win over Turkey.

Russia has relied on the containment and non-escalation policy as a basis for its foreign policy towards Turkey as it could represent an entry point that could penetrate the alliance and sow discord within it, and thus weakening it, especially that Turkey is the second-largest army of the alliance in terms of number, as well as the most significant ally in the southeast. In addition to hosting, one of the crucial military bases is the Turkish Incirlik air base (Karam, 2019). ${ }^{(81)}$ The most important manifestations of this Russian orientation towards Turkey appeared in the following:-

(a) Provisioning Turkey with advanced military equipment: The distinctive cooperative relations between Russia and Turkey in various areas, mainly, 
energy were reflected in the Russian side providing sophisticated weapons to Turkey that it did not offer many of its historical allies. The two partners signed on September 2017 an agreement under which Russia will sell advanced S400 Triumph air missile defense systems (Nikolskly, 2019). ${ }^{(82)}$ This advanced system integrates a multifunction radar, autonomous detection and targeting systems, anti-aircraft missile systems, launchers, and command and control center. It is capable of firing three types of missiles to create a layered defense. The system also can engage all types of aerial targets, including aircraft, unmanned aerial vehicles (UAV), and ballistic and cruise missiles, within the range of $400 \mathrm{~km}$ at an altitude of up to $30 \mathrm{~km}$ as well as it can simultaneously engage 36 targets (Army Technology, 2020). ${ }^{(83)}$

The Russian-Turkish deal much resented the United States, prompting Washington to invite Ankara to reconsider it, and also warned that if it went ahead, Ankara would be excluded from the F-35 warplanes program to arm NATO forces over the coming years (Marcus, 2019). ${ }^{(84)}$

On the other hand, Turkey stuck to the completion of the deal without submitting to United States pressure, as Turkish President Recep Tayyip Erdogan on 8 April 2019 affirmed that its Turkey's right to have this advanced defense system, stressing that "It is our sovereign right. No one can demand we waive it" (Tass, 2019). ${ }^{(85)}$

Russia took advantage of that tough American stance towards Turkey to further consolidating its relations. In November 2019, the Head of the state hitech corporation, Rostec, Sergei Chemezov, offered to deliver both generation 4++ Su-35 and fifth-generation Su-57 fighters to Turkey (Lystseva, 2019). ${ }^{(86)}$ The Su-35 is a $4^{\text {th }}$ generation multirole super-maneuverable fighter equipped 
with a phased array radar, as well as thrust-vectoring engines (Military Factory, 2020). ${ }^{(87)}$ While The Su-57 is a 5 th generation multirole fighter designed to demolish all types of air, ground, and naval targets (Military Factory, 2019). ${ }^{(88)}$

(b) Overlooking political and diplomatic Turkish inaccuracies :Based on the Russian non-escalating tendency toward Turkey. The Russian position seemed moderate towards some of the irresponsible Turkish political actions. And that is evidenced by two main events, as follows:-

- Moderate Russian reaction to the assassination of its ambassador in Ankara: Contrary to what was expected, the assassination of the Russian ambassador in Ankara did not affect the course of relations between the two countries but increased cooperation between them. This was most evident in the statements of high-ranking Russian officials, including the Russian Foreign Minister Sergey Lavrov, saying that the murder of Andrei Karlov "make all of us fight terrorism more decisively". In addition to the statement of Dmitry Peskov, Russian president spokesman man, who asserted that "This will not harm the negotiation peace process in Syria with turkey"-adding that "A Street in Ankara would be named after Karlov" (Seddon, 2016). ${ }^{(89)}$

- Russia's poor reaction to the downing of its warplane in Syria by Turkish force: Despite the diplomatic crisis that erupted between Russia and Turkey in November 2015, based on downing the Russian plane by Turkish F-16 led to Russia imposing economic sanctions on Turkey. However, once Turkish President Recep Tayyip Erdogan offered an apology, which his Russian counterpart Vladimir Putin accepted, the relations between them returned to his previous era (Koutroumpis, 2019). ${ }^{(90)}$

(c) Giving Turkey the upper hand over European energy security: the setting up of the new Turkstream gas pipeline in January 2020 that would transfer 
Russian gas through Turkish territories to Europe, which represents an alternative to the Ukrainian corridor, gave Turkey a unique comparative advantage of great importance against Europe, as it not only strengthened its position and role as the energy hub, but also contributed in giving it more control over the paths of transferring energy resources to Europe, and that will change the balance of power relations between the European and Turkish parties as it represents a new pressure card that did not exist before (Furuncu, 2020, P.11). (91)

\section{Conclusion}

It seems that energy ties have become one of the most crucial determinants of the country's foreign policy, especially the major ones, which seek to extend their influence at both global and regional levels. This importance increases as long as these countries rely heavily on hydrocarbon export revenues to achieve high economic growth levels, a goal that was announced by many high-ranking Russian officials, led by Russian President Vladimir Putin. Thus, Russia found all essential requirements in Turkey to be an optimal energy partner, as it represents the main corridor for transferring energy resources to Europe. This advantage pushes the Russians to consolidate their relations with it.

These significant energy relations reflected in a large scale of political manifestations, among the most prominent of them is granting Turkey various political, strategic, military, and political advantages, in the forefront: a relatively

flexible dealing with Turkey in various controversial issues, such as Syrian and Libyan dilemmas, as well as giving indirect support for Turkish East Mediterranean activities. In addition to overlooking the Russian ambassador's assassination in Ankara and the downing of its warplane near the Syrian-Turkish 
border. Moreover, provisioning Turkey with a modern defense system that has not been given to its allies.

\section{$\underline{\text { References }}$}

1)ElBassoussy, A.(2019) The struggle for Eastern Mediterranean gas and opportunities for cooperation. $1^{\text {st }}$ ed., Arab Knowledge Bureau, Cairo, Egypt, P. 69.

2)Bell, D. (2013) "Realism”, Encyclopedia Britannica, available at:

https://www.britannica.com/topic/realism-political-and-social-science, (accessed on 3

December 2013).

3)Behravesh, M. (2010) "Realism and Neorealism: An Investigative Overview", eInternational Relations (e-IR), available at: http://www.e-ir.info/2010/12/19/realism-andneorealism-an-investigative-overview/ (accessed on 10 November 2018).

4)Stanford Encyclopedia of Philosophy (2010),"Political Realism in International Relations", available at: https://plato.stanford.edu/entries/realism-intl-relations/. (accessed on 3

December 2018)

5)Rose, G.(1998) , "Neoclassical Realism \& Theories of Foreign Policy”, World Politics, Vol. 51, No.3, P. 144 .

6)Donnelly, J. (2000) , Realism and International Relations, $1^{\text {st }}$ ed., Cambridge University Press, London, PP 9-11.

7)Cesnakes, G. (2010) "Energy Resources in Foreign policy: A Theoretical Approach", Baltic Journal of law \& politics, vol. 3, No.1, P 33.

8)/bid, P. 84.

9)Herz, J. (1981) Political realism revisited , International Studies Quarterly, vol. 25, No.2, P. 46.

10)Griffiths, M., Roach, S., Solomon, S. (2009) "Fifty Key Thinkers in International Relations", $2^{\text {nd }}$ ed., Routledge, London, P. 46.

11)Powell, R.(1994) Anarchy in International Relations Theory: The Neorealist -Neoliberal Debate, International Organization, Vol.48, No.2, P. 314. 
12)Waltz, K . (1979) "Theory of International Politics", $1^{\text {st }}$ ed., Addison Wesely Publishing, Philippines. P. 146.

13)Gurbanov, L.(2013) "Energy Security Dimension in Foreign Policy", Strategic Outlook, available at: http://www.strategicoutlook.org/philosophy/news-energy-security-dimensionin-foreign-policy.html (accessed 18 October 2018).

14)Snyder, G.(2002) Mearsheimer's World-Offensive Realism \& the Struggle for security: A Review Essay, International Security, Vol. 27, No.1, P. 150.

15)Mearsheimer, J.(2001) "The Tragedy of Great Power Politics", W.W.Norton \& Company, New York, P. 29.

16) Ibid, PP 66-67.

17)Cesnakes, G. (2010), Op.cit., P 41.

18)Hamilton, E. and Rathun, B. (2013) Scarce Differences: Toward a Material and Systemic foundation for Offensive \& Defensive Realism, Security Studies, Vol.22, P 445.

19)Walt, S.(1998) Alliance Formation and the Balance of Power, International Security, Vol. 9, No.4, P. 15.

20)Brooks, S. (1997), Dueling Realisms, International Organization, Vol. 51, No.3, PP 440452.

21)Gurbanov, L.(2013), Op.cit.

22)Rose, G.(1998), Op.cit., P 146.

23)Wohlforth, W.(1998) The stability if a Unipolar World, International Security, Vol. 24, No.1, P. 10 .

24)Zakaria, F.(1998), "From Wealth to Power",Princeton University Press, New Jersey, P.12.

25)Klare, M.(2001) The New Geography of Conflict, Foreign Affairs, vol. 80, No.3, P. 50. 26)Klare, M.(2008) "Rising Powers, Shrinking Planet How Scarce Energy Creating a New World Order", One World Publications, Oxford, London, P. 7.

27)Klare, M.(2009) "There Will Be Blood: Political Violence, Regional Warfare, and the Risk of Great- Power Conflict over Contested Energy Resources”, in K., Anne and L., Gal (Eds), 
Energy Security Challenges for the $21^{\text {st }}$ Century, $1^{\text {st }}$ ed., Greenwood Publishing, United States. P. 47.

28)Badie, B., Berg-Schlosser, D., Morlino, L. (2011), "International Encyclopedia of Political Science", Vol. 1 , Sage Publications, Inc., Los Angeles, United States.

29)Gücüyener, A.(2017) "The Clash of Realism and Liberalism: Understanding the Nature of Cooperation on Energy Security between Turkey-Azerbaijan and Georgia”, The Market for Ideas, 2/2017. available at:: http://www.themarketforideas.com/the-clash-of-realism-andliberalism-understanding-the-nature-of-cooperation-on-energy-security-between-turkeyazerbaijan-and-georgia-a181/. (accessed on 12 December 2018).

30)Keohane, R., and Nye, J.(2012) "Power and Interdependence", $4^{\text {th }}$ ed., Longman, New York, P. 3.

31) Ibid, P 288.

32)Keohane, R. and Victor, D. (2013) The Transitional Politics of Power, The Journal of American Academy of Arts \& Science, Vol.142, No.1, P. 99.

33)Dannreuther, R. (2010) "International Relations Theories: Energy, Minerals, \& conflict",

Polinares Working Paper, Study Lib, available at:

https://studylib.net/doc/8824990/international-relations-theories--energy--minerals (accessed on 1 May 2018).

34)Schmidt, V.(2014) "Institutionalism", The Encyclopedia of Political Thought, Research Gate, available at: https://www.researchgate.net/publication/313505827_Institutionalism (Accessed on 10 November 2018).

35)Hall, P. and Taylor, R.(1996) Political Science and the Three New Institutionalism, Political Studies, Vol.44.

36) Belyi, A.(2018) "Energy Security in Interantional Relations (IR) Theories", Higher School of Economics, available at:

https://www.hse.ru/data/.../ReaderforLecturesOnEnergySecurity.doc. (Accessed on 17 December 2018).

37)Workman, D.(2020), " Russia's Top 10 Exports”, available at:

http://www.worldstopexports.com/russias-top-10-exports/ (accessed on 15 March 2020) 
38)British Petroleum (2019), "BP statistical review of world energy June 2019", Energy Outlook, London, P. 16. Available at: https://www.bp.com/content/dam/bp/businesssites/en/global/corporate/pdfs/energy-economics/statistical-review/bp-stats-review-2019full-report.pdf (accessed 10 July 2019).

39) Ibid, P.32.

40) Ibid, P.30.

41) Ibid, P.14.

42)/bid, P.38.

43) Ibid, P.29.

44)Campos, A. (2018), "Russia's Energy Strategy: Challenges and Foreign Energy Policy", FCSH, P. 51. Available at:

https://pdfs.semanticscholar.org/649c/1890fc05edd70923f98a8a970cb2419029ac.pdf (accessed on 3 May 2019)

45)Ministry of Energy of the Russian Federation (2010), "Energy Strategy of Russia for the period up to 2030", available at: http://www.energystrategy.ru/projects/docs/ES-

2030_(Eng).pdf (accessed on 4 June 2019)

46)Campos, A. (2018), Op.Cit, P. 52.

47)Mitrova, T. and Yermakova, V.(2019), " Russia's energy strategy -2035: Struggling to remain relevent”, IFRI Russia/NIS Center, P. 13. Available at:

https://www.ifri.org/sites/default/files/atoms/files/mitrova_yermakov_russias_energy_strateg y_2019.pdf (accessed on 15 March 2019)

48)British Petroleum (2019), Op.Cit, P.40.

49)Hydrocarbons Technology (2019), “ The Blue Stream Pipeline Project, Europe”,

available at: https://www.hydrocarbons-technology.com/projects/bluestream-pipeline/ (accessed on 13 February 2019)

50)Eurasia Review (2020), " TurkStream to Intensify Russia-Turkey Relations: Strengthen Russia's Position In EU Energy Market - Analysis”, available at:

https://www.eurasiareview.com/05022020-turkstream-to-intensify-russia-turkey- 
relations-strengthen-russias-position-in-eu-energy-market-analysis/ (assessed on 1

March 2020)

51)Gazprom (2020), “ Turkstream: Gas exports to Turkey and southeastern Europe”, available at: https://www.gazprom.com/projects/turk-stream/ (accessed on 1 January 2020) 52)Eurasia Review (2020), Op.cit.

53)Prince, T. (2020), "Russia Launches Into New Export Territory With TurkStream NaturalGas Pipeline", available at: https://www.rferl.org/a/russia-launches-itself-into-new-exportterritory-with-turkstream-natural-gas-pipeline/30364755.html (accessed on 10 January 2020)

54)Zender, A.(2019) “ Turkish Stream or Russian Stream: Who gets the most profit from the pipeline?", available at: https://behorizon.org/turkish-stream-or-russian-stream-who-getsthe-most-profit-from-the-pipeline/ (accessed on 10 March 2019)

55)Bauomy, J. (2020), "TurkStream: Europe needs gas and Russia has it - the story behind that new pipeline", available at: https://www.euronews.com/2020/01/08/turkstreameurope-needs-gas-and-russia-has-it-the-story-behind-that-new-pipeline (accessed on 1 Februray 2020)

56)Coyle,J.(2019),"Europe deepens energy dependence on Russia”, available at: https://thehill.com/opinion/energy-environment/474818-europe-deepens-energydependence-on-russia (accessed on 25 December 2019)

57)Xiaoqiong, G.(2020), “What does TurkStream mean for Russia and Turkey?”, available at:https://www.chinadaily.com.cn/a/202001/08/WS5e152ec0a310cf3e355831cb.html (accessed on 20 January 2020)

58)Saygin, D., Hoffman, M ., Godron, P. (2018) “ How Turkey Can Ensure a Successful Energy Transition", Center for American Progress, Foreign Policy And Security, available at: https://www.americanprogress.org/issues/security/reports/2018/07/10/453281/turkey-canensure-successful-energy-transition/ (accessed on 10 October 2019)

59)Tekin, A. and Walterova, I. (2007), Turkey's Geopolitical Role: The Energy Angle, Middle East Policy, Vol.14, No.1, P.10. 
60)Reuters (2019), " Turkey and Azerbaijan mark completion of TANAP pipeline to take gas

to Europe", available at: https://www.reuters.com/article/us-turkey-energy-tanap/turkeyand-azerbaijan-mark-completion-of-tanap-pipeline-to-take-gas-to-europe-

idUSKBN1Y40CP (accessed on 3 December 2019)

61)Xiaoqiong, G.(2020), Op.cit.

62)Tiftikçigil, B., and Yesevi C. (2014), Energy Relations between Turkey and Russia: Conflict in Energy Project, Journal of Economics and Sustainable Development, Vol. 5, No.12, P. 63.

63)Persee, J. (2016), Baku-Tbilisi-Ceyhan Pipeline - Geopolitical benefits for the countries it goes through, BTC Analsysis, 19/9/2016, available at:

https://www.researchgate.net/publication/309528504_Baku-Tbilisi-Ceyhan_Pipeline_-

Geopolitical_benefits_for_the_countries_it_goes_through (accessed on 16 November $\underline{2019)}$

64)Baran, Z.(2005) “ The Baku-Tblisi-Ceyhan Pipeline: Implications for Turkey”, in S. Frederick and C. Svante (Eds), The Baku-Tbilisi-Ceyhan Pipeline: Oil Window to the west, Centarl Asian Caucauses Institute, Silk Road studies Program, Johns Hopkins University, Washington, D.C., United States, P. 109.

65) Ibid, P. 115.

66)Hydrocarbons Technology(2002),"Nabucco Gas Pipeline, Europe”, available at: https://www.hydrocarbons-technology.com/projects/nabuccopipeline/ (accessed on 3 November 2019)

67)Gotev, G.(2012), "Final decision on South Stream pipeline in sight", available at: https://www.euractiv.com/section/energy/news/final-decision-on-south-stream-pipelinein-sight/ (accessed on 17 May 2019)

68)Offshore Technology (2008), “ South Stream Vs Nabucco”, available at: https://www.offshore-technology.com/features/feature1643/ (accessed on 12 June 2019) 69)BBC News(2014), "Russia drops South Stream gas pipeline plan", available at: https://www.bbc.com/news/world-europe-30283571 (accessed on 3 August 2019) 
70)Stren, J., Piran, S., Yafimava, K.(2015), “ Does the cancellation of South Stream signal a fundamental reorientation of Russian gas export policy?", The Oxford Institute For Energy Studies, P.5, available at: https://www.oxfordenergy.org/wpcms/wpcontent/uploads/2015/01/Does-cancellation-of-South-Stream-signal-a-fundamentalreorientation-of-Russian-gas-export-policy-GPC-5.pdf?v=fbe46383db39 (accessed on 3 November 2018)

71)Jones, I. (2017), "Why does Russia support Syria and President Assad?", available at: http://www.bbc.co.uk/newsbeat/article/39554171/why-does-russia-support-syria-andpresident-assad (accessed on 15 May 2019)

72) kasapoğlu, C., Ergun, D., Ulgen S., (2015), “ A Turkish Intervention in Syria: A Reality Check", Edam Center for Economics and Foreign Policy, EDAM Disscussion paper series 2015/2, P.3, available at: https://edam.org.tr/wpcontent/uploads/2015/07/EDAM_Turkish_Intervention_Syria.pdf (accessed on 23 June 2019)

73)Barnard, A. (2017), "Assad Must Go, Erdogan Says, as Syria War Winds Down”, The New York Times, 27/12/2017, available at:

https://www.nytimes.com/2017/12/27/world/middleeast/syria-evacuations.html (accessed on 25 July 2019)

74)McKernan, B. (2020), Erdogan threatens Assad with retaliation if more troops harmed, The Guardian, 12/2/2020, available at:

https://www.theguardian.com/world/2020/feb/12/erdogan-threatens-assad-withretaliation-if-more-troops-harmed-syria-turkey (accessed on 12 February 2020) 75)Gebert, A. (2020), Russia and Turkey are close but will disagree, Lavrov says, Reuters, 15/2/2020, available at:https://www.reuters.com/article/us-germany-security-lavrov/russiaand-turkey-are-close-but-will-disagree-lavrov-says-idUSKBN2090LJ (accessed on 1 March 2020)

76)Roth, A. (2020), "Russia and Turkey agree ceasefire in Syria's Idlib province", The guardian. Available at:https://www.theguardian.com/world/2020/mar/05/russia-and-turkey$\underline{\text { agree-ceasefire-in-syrias-idlib-province (accessed on } 17 \text { June 2020) }}$ 
77)Starodubtsev, I. (2019) "Will Russia Back Turkey in the Eastern Mediterranean?", Politics Today. Available at: https://politicstoday.org/will-russia-back-turkey-in-the-easternmediterranean/ (accessed on 20 June 2020)

78)New Europe (2019), "Euope's leaders to reject Turkey-Libya maritime border deal”. Available at: https://www.neweurope.eu/article/europes-leaders-to-reject-turkey-libyamaritime-border-deal/ (accessed on 18 June 2020)

79)Ahval (2020), “ Turkey's maritime deal with Libya provocative- U.S State department”. Available at: https://ahvalnews.com/eastern-mediterranean/turkeys-maritime-deal-libyaprovocative-us-state-department (accessed on 18 June 2020)

80)Ahval (2019) " Turkey calls the Eastern Mediterranean to cooperate with it, and Russia is ready for exploration". Available at: https://ahvalnews.com/ar/trkya-tdw-shrq-almtwstIltawn-mha-wrwsya-mustdwt-Iltnqyb/syast (accessed on 14 June 2020)

81)Karam, M.(2019), " Russia is spreading discord in NATO", France 24. Available at: shorturl.at/iyHY1 (accessed on 21 June 2020)

82)Nikolskly, A. (2019), “ Turkey to get Russia's S-400 missile system by July, Erdogan says", available at: https://tass.com/defense/1052967 (accessed on 10 May 2019) 83)Army Technology (2020)," S-400 Triumph Air Defence Missile System”, available at: https://www.army-technology.com/projects/s-400-triumph-air-defence-missile-system/ (accessed on 2 February 2020)

84) Marcus, J. ( 2019), "What Turkey's S-400 missile deal with Russia means for Nato", available at: https:/www.bbc.com/news/world-europe-48620087 (accessed on 13 July $\underline{2019}$

85)Tass (2019), “ Erdogan says it is Turkey's sovereign right to buy Russian S-400 systems", available at: https://tass.com/defense/1052731 (accessed on 8 July 2019) 86)Lystseva, M. (2019), "Russia ready to deliver both Su-35 and Su-57 fighters to Turkey”, available at: https://tass.com/defense/1089857 (accessed on 10 Decmber 2019 87)Military Factory (2020), “ Sukhoi Su-35 (Flanker-E/ Super Flanker): Multirole Heavy Combat Fighter Aircraft", available at: 
https://www.militaryfactory.com/aircraft/detail.asp?aircraft_id=88 (accessed on 20 February 2020)

88)Military Factory (2019), " Sukhoi Su-57 (T-50/ PAK FA): 5th Generation Muti-Role Stealth Aircraft", available at:

https://www.militaryfactory.com/aircraft/detail.asp?aircraft_id=782 (accessed on 1 January 2020)

89)Seddon, M. (2016), Russia and Turkey vow to keep détente on track after killing,

Financial Times, available at: https://www.ft.com/content/4e34cd2e-c696-11e6-9043-

7e34c07b46ef (accessed on 3 November 2019)

90) koutroumpis, J., (2019), " Russia and Turkey: An Ambiguous Energy Partnership”, available at: https://www.e-ir.info/2019/09/11/russia-and-turkey-an-ambiguous-energypartnership/ (accessed on 7 December 2019)

91)Furuncu, Y. (2020) “ The New Dimension Of The Turkey-Russia Energy Cooperation Turkstream", SETA Analysis. available at:

https://setav.org/en/assets/uploads/2020/01/A57En.pdf (assessed on 21 June 2020) 